\title{
Így kezeljük az autológ őssejt-transzplantáció után kiújult Hodgkin-lymphomát
}

\author{
Illés Árpád dr. - Simon Zsófia dr. - Udvardy Miklós dr. \\ Magyari Ferenc dr. - Jóna Ádám dr. - Miltényi Zsófia dr. \\ Debreceni Egyetem, Általános Orvostudományi Kar, Belgyógyászati Intézet, Hematológiai Tanszék, Debrecen
}

\begin{abstract}
Az elsődleges kezelés után a Hodgkin-lymphomás betegek 10-30\%-a relabál vagy refrakter. Jelenleg elsőként autológ haemopoeticus őssejt-transzplantáció javasolt ezekben az esetekben, bár ezt követően csak a betegek fele gyógyul meg, a medián teljes túlélés is mindössze 2-2,5 év. Számos prognosztikai tényező határozza meg az autológ haemopoeticus őssejt-transzplantáció sikerességét, amelyek figyelembevételével, szükség esetén konszolidációs kezelés alkalmazásával az eredmények javíthatók. Az autológ őssejt-transzplantáció után relabáló betegeknek még kedvezőtlenebb a túlélése, és ennek a betegcsoportnak a kezelése jelenti a legnagyobb kihívást a Hodgkin-lymphoma terápiája során. Szerencsére az utóbbi években számos új kezelési mód vált elérhetôvé, így a brentuximab vedotin és az immuncheckpoint-gátlók, amelyektôl a túlélési és gyógyulási eredmények javulását reméljük. Az allogén transzplantáció eredményei is javulhatnak a haploidentikus transzplantáció alkalmazásával. Összefoglalónkban ezeket az új lehetőségeket mutatjuk be.
\end{abstract}

Orv Hetil. 2017; 158(34): 1338-1345.

Kulcsszavak: Hodgkin-lymphoma, relapsus, haploidentikus transzplantáció, brentuximab vedotin, PDl-gátlás

\section{Treatment of relapsed Hodgkin lymphoma after autologous stem cell transplantation}

Approximately 10-30\% of Hodgkin lymphoma patients relapses or experience refractory disease after first line treatment. Nowadays, autologous stem cell transplantation can successfully salvage half of these patients, median overall survival is only 2-2.5 years. Several prognostic factors determine success of autologous stem cell transplantation. Result of transplantation can be improved considering these factors and using consolidation treatment, if necessary. Patients who relapse after autologous transplantation had worse prognosis, treatment of this patient population is unmet clinical need. Several new treatment options became available in the recent years (brentuximab vedotin and immuncheckpoint inhibitors). These new treatment options offer more chance for cure in relapsed/refractory Hodgkin patients. Outcome of allogenic stem cell transplantation can be improved by using haploidentical donors. New therapeutic options will be discussed in this review.

Keywords: Hodgkin lymphoma, relapse, haploidentical transplantation, brentuximab vedotin, PDl inhibitor

Illés Á, Simon Zs, Udvardy M, Magyari F, Jóna Á, Miltényi Zs. [Treatment of relapsed Hodgkin lymphoma after autologous stem cell transplantation]. Orv Hetil. 2017; 158(34): 1338-1345.

(Beérkezett 2017. június 6.; elfogadva: 2017. július 1.)

\section{Rövidítések}

ABVD = adriamycin, bleomycin, vinblastin, dacarbazin; AHSCT = autológ haemopoeticus őssejt-transzplantáció; ALCL $=$ anaplasticus nagy sejtes lymphoma; allo-SCT $=$ allo- gén haemopoeticus őssejt-transzplantáció; ASHAP = adriamycin, metilprednizolon, cytarabin, ciszplatin; BEAM = carmustin, etopozid, cytarabin és melfalan; BV = brentuximab vedotin; $\mathrm{cHL}=$ klasszikus Hodgkin-lymphoma; ChlVPP = chlorambu- 
cil, vinblastin, procarbazin, prednizon; $\mathrm{CR}=$ komplett remiszszió; DHAP = dexamethason, cytarabin, ciszplatin; EFS = eseménymentes túlélés; FDA = Food and Drug Administration; GDP = gemcitabin, dexamethason, ciszplatin; GVHD = graft versus host betegség; HDACi: hiszton-deacetiláz-gátló; $\mathrm{HL}=$ Hodgkin-lymphoma; HLA = humán leukocyta-antigén; ICE = ifoszfamid, karboplatin, etopozid; IFRT = érintett mezős irradiáció; IGEV = ifoszfamid, gemcitabin, vinorelbin; KMR = komplett metabolikus remisszió; $\mathrm{LC}=$ helyi kontroll; $\mathrm{MRD}=$ HLA-identikus rokon donor; MUD = nem rokon donor; $\mathrm{NRM}=$ nem relapsusból eredő mortalitás; NS = nodular sclerosis; $\mathrm{OS}=$ teljes túlélés; $\mathrm{ORR}=$ teljes válaszarány $\mathrm{PD}=\operatorname{prog}$ ramozott sejthalál; $\mathrm{PET} / \mathrm{CT}=$ pozitronemissziós tomográfia/ komputertomográfia; PFS = progressziómentes túlélés; $\mathrm{PR}=$ részleges remisszió; $\mathrm{R}-\mathrm{BEAM}-\mathrm{Br}=$ rituximab, carmustin, etopozid, cytarabin, melfalan, brentuximab vedotin; RFS = relapsusmentes túlélés; RIC = redukált intenzitású kondicionálás; $\mathrm{RT}=$ radioterápia; TRM = transzplantációhoz kapcsolt mortalitás; VOD = venookkluzív betegség

Az elsődleges kezelés után relabáló vagy refrakter Hodgkin-lymphomás (HL-) betegek kezelése napjainkban is nagy kihívást jelent. Jelenleg elsőként nagy dózisú kemoterápia és autológ haemopoeticus őssejt-transzplantáció (AHSCT) javasolt ezekben az esetekben. Bár csak a betegek 50-60\%-a gyógyul meg [1], és a medián teljes túlélés (OS) is mindössze 2-2,5 év [2, 3]. Az AHSCT után relabáló betegeknek még kedvezőtlenebb a túlélése, de az utóbbi években számos új kezelési mód vált elérhetővé, amelyektől a túlélési és gyógyulási eredmények javulását reméljük.

\section{Az AHSCT utáni relapsus}

Az AHSCT utáni relapsust számos, a transzplantáció előtti tényező befolyásolja, így a betegség kiújulásának rizikója fokozott, ha a transzplantáció időpontjában nem volt a betegség komplett metabolikus remisszióban ${ }^{18}$ FDG-PET/CT alapján; ha a relapsus egy éven belül következett be; ha extranodalis érintettség volt; illetve, ha a Karnofsky-státusza a betegnek <90\% [4-7]. A legfontosabb prognosztikai tényező az utóbbi évek eredményei alapján a transzplantáció előtti remisszió mértéke, így az AHSCT előtti negatív PET/CT [8-10].

Az AHSCT-t követő relapsusban a beteg és a betegség jellemzőitől, illetve a kezelés céljától függően bár számos terápiás lehetőség közül választhatunk, de az még nem ismert, hogy hosszú távon ezek mennyire lesznek sikeresek, milyen késői mellékhatások alakul(hat)nak ki. A kezelés megválasztásához szükség esetén ismételt biopsziát kell végezni, pontosan fel kell mérni a betegség stádiumát, rizikófaktorokat, a beteg általános állapotát, társbetegségeit, amelyek alapján eldönthető, milyen kezelést bír el a beteg. A kezelés céljának (kuratív, bridging allogén transzplantáció, palliatív) meghatározását követően - figyelembe véve a korábban alkalmazott kezelés(eke)t, az erre adott terápiás választ és mellékhatásokat, a beteg és hozzátartozójának kérését - kell megválasztanunk a terápiát.

Amennyiben kuratív célú a kezelés, úgy jelenlegi ismereteink alapján allogén transzplantáció javasolt. Az új kezelési módszerek közül még nem bizonyított egyikről sem, hogy tartósan komplett remissziót, gyógyulást eredményezne.

A minél mélyebb és tartósabb remisszió elérése bármely kezelési formával azonban nemcsak az allogén transzplantációra kerülő betegeknél fontos, hanem azoknál a betegeknél is, akik a transzplantációra eleve nem alkalmasak életkoruk, általános állapotuk vagy kísérő betegségeik miatt. Hosszú távú túlélésüket, gyógyulásukat a remisszió határozza meg elsődlegesen, amelynek eléréséhez számos új terápiával rendelkezünk (1. ábra). Három rövid esetünk a jelenlegi mindennapi gyakorlatunkat mutatja be, ezt követően részletesen ismertetjük a kezelési módszereket.

\section{Allogén haemopoeticus őssejt-transzplantáció}

Az AHSCT után relabáló betegek prognózisa kedvezőtlen, a medián túlélés a transzplantációt követő relapsustól 12-29 hónap $[2,11,12]$.

Bár a jelenlegi ajánlások ilyenkor allogén transzplantációt (allo-SCT) javasolnak, ez ritkán hoz gyógyulást, metaanalízis alapján az egyéves relapsusmentes túlélés (RFS) 50\% (három évnél 31\%) [13].

Az allo-SCT sikerességét is számos klinikai tényező befolyásolja, így hosszabb teljes túlélésre azok a betegek számíthatnak, akiknek a betegsége kemoszenzitív, jó általános állapotúak, CR-t értek el az allo-SCT előtt. Az AHSCT után hat hónapon belül relabálók rosszabb PFSre számíthatnak [14].

Az eredményeket a kondicionáló kezelések is befolyásolják, így a redukált intenzitású kondicionáló (RIC) ke-

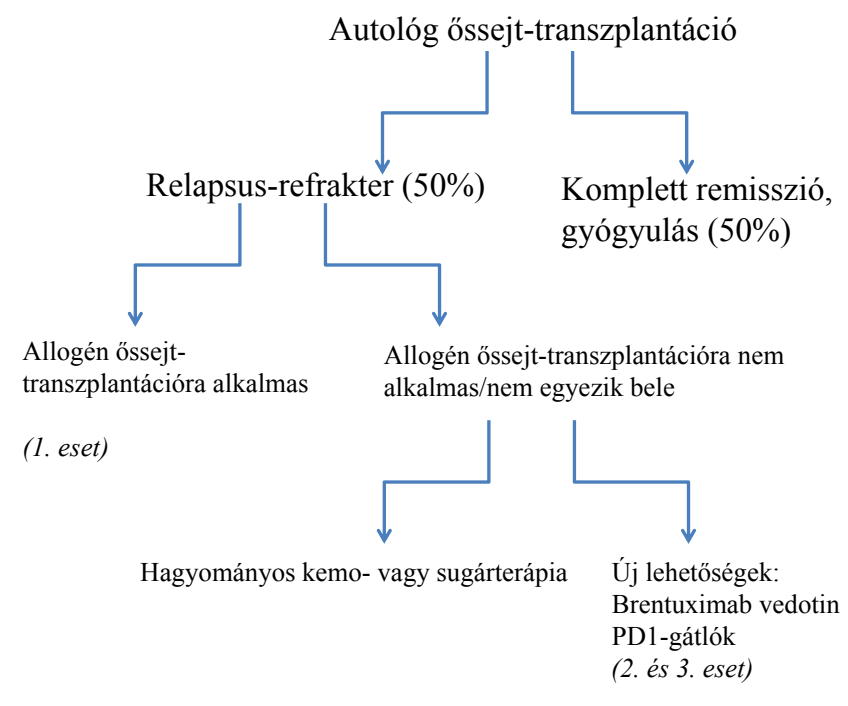

1. ábra $\quad$ Autológ őssejt-transzplantáció után relabáló Hodgkin-lymphomás beteg kezelése 
zeléssel végzett allogén transzplantáció kedvezőbb, mint a myeloablativ kondicionálással végzett, mivel a nem relapsusból eredő mortalitás (NRM) gyakoribb (23\% vs. 46\%) abban a csoportban, ahol myeloablativ kondicionálást kaptak. Az NRM különösen gyakori azoknál, akiknél korábban AHSCT-t végeztek és myeloablativ kondicionálást kaptak [15]. A HLA-identikus rokon donor (MRD-) graft használata a standard, ilyenkor az NRM körülbelül 10\%. Amennyiben nincs rokon donor, úgy idegen donor (MUD) keresése szükséges, még akkor is, ha az NRM ezekben az esetekben már 28\% [16].

Mivel ezeknek az allogén transzplantációknak az eredménye nem elég jó (jelentős NRM és csekély túlélés), így mindenképpen szükséges más kezelési lehetőségeket keresni.

Az egyik lehetőség a haploidentikus családi donorok és poszttranszplantációs ciklofoszfamid alkalmazása, ami mellett javuló eredményeket észleltek. Burroughs és mtsai vizsgálata alapján, amelyben az MRD, MUD és haploidentikus donorok transzplantációjával elért eredményeket elemezték, a haploidentikus donor alkalmazásakor mind a PFS, mind az NRM és a relapsusarány is szignifikánsan kisebb volt, úgy, mint az akut és krónikus GVHD incidenciája is [17]. A GVHD és a graftrejekció csökkentésében a haploidentikus transzplantáció után korán alkalmazott nagy dózisú ciklofoszfamidkezelés segíthet az alloreaktív donor és saját T-sejtek elpusztításával, de nem befolyásolja a megtapadást a haemopoeticus őssejtek ciklofoszfamiddal szembeni enzimatikus rezisztenciája miatt (feltehetően, mert ezek a sejtek nem osztódnak) [17]. Raiola és mtsai 26 cHL-es betegnél végeztek haploidentikus transzplantációt, amelynek időpontjában a betegek 65\%-ánál aktív betegség volt észlelhető. A PFS $63 \%$, az OS $77 \%$, a relapsusarány $31 \%$ és az NRM 4\% volt, és szintén alacsony volt az akut és krónikus GVHD gyakorisága [18]. Gayoso és mtsai 29 HL-es betegnél végeztek haploidentikus transzplantációt, a betegek 72\%ánál a betegség aktív volt (PET-pozitív) a transzplantáció elvégzésekor. Akut és krónikus GVHD-t a betegek 25 és 10\%-ában észleltek. A kilenc hónapos medián követésnél a betegek 59\%-a élt és komplett remisszióban volt [19].

Bár a 2000-es évektől kezdve az allogén transzplantáció eredményei Hodgkin-lymphomában is javultak, a hároméves RFS és OS 25\%-ról 40\%-ra, illetve 39\%-ról 60\%ra [13] nőtt, ez még hosszú távon mindig nem elegendő. Sajnos, a betegek egy része nem is alkalmas allogén transzplantációra (kemorefrakteritás, társbetegségek, életkor stb.), vagy rokon donor hiányában évekig tart a megfelelő nem rokon donor keresése. Így ebben a nagyon rossz prognózisú csoportban fontos az új kezelési lehetőségek keresése, a haploidentikus transzplantáció további elemzése.

\section{Korai peritranszplantációs sugárkezelés}

ASCT után leggyakrabban a korábban már érintett nyirokcsomó-régiókban alakul ki relapsus [20-22], így fel- merül a peritranszplantációs időszakban a sugárkezelés alkalmazása, hogy a túlélést növelhessük, de a pontos kezelésre irányelvek nincsenek. Milgrom és mtsai 139, AHSCT-n átesett HL-es beteg között vizsgálták a peritranszplantációs sugárkezelések jellemzőit. A betegek 12\%-a (22 beteg) kapott az AHSCT körül négy hónapon belül sugárkezelést (2l beteg az AHSCT után). Szignifikánsan több beteg részesült sugárkezelésben, ha primer refrakter betegségük volt; a transzplantáció idején betegségük aktív volt (PET-pozitív); a betegség korai stádiumú volt a diagnózis vagy a relapsus idején; illetve kisebb arányban volt extranodalis betegségük. A peritranszplantációs RT-ben részesült és nem részesült betegeknél ugyanolyan arányban fordult elő relapsus (32\% és 31\%), de az RT-ben részesültek között kevesebb volt a lokális relapsus (18\% vs. 31\%). Grade>2 RT indukálta toxicitást, pancytopeniát észleltek, bár ennek hátterében az alapbetegség csontvelői érintettsége is felmerült. Sem pneumonitis (egy beteg kivételével mindenki részesült mediastinalis irradiációban), sem késői grade $>2$ toxicitás nem alakult ki. Univariáns analízissel a peritranszplantációs RT nem befolyásolta a helyi tumorkontrollt, a PFS- $t$ vagy OS-t, bár valószínúleg ebben szerepet játszik az is, hogy a sugárkezelést bizonyos betegeknél gyakrabban alkalmazták (primer refrakter betegség, aktív betegség a transzplantációkor). Ezekben a csoportokban a négyéves lokális kontroll 81\% volt az RT-ben részesülő betegekben, szemben azokkal, akik nem kaptak RT-t (49\%, p = $0,03)$. Ez alapján a relapsus szempontjából nagy rizikójú betegeknél alkalmazása előnyösnek tűnik [23].

Az RT dózisát vizsgálva felmerült, hogy a kemorefrakter betegeknek $\geq 35$ Gy RT alkalmazása szükséges lehet $[23,24]$. Az RT alkalmazása döntően az AHSCT után javasolt, hiszen előtte alkalmazva a betegség a nem besugarazott területeken progrediálhat, illetve a csontvelő károsításával az aplasia idejét nyújthatja [23].

Levis és mtsai 73 betegnél vizsgálták a peritranszplantációs RT szerepét. A betegek 28,8\%-a kapott IFRT-t (hat beteg az AHSCT elött, 15 beteg utána). Az IFRTben részesülők rosszabb prognosztikai tényezőkkel rendelkeztek, szignifikánsan kevesebben kerültek CR-be az elsődleges kezelésre, több volt közöttük az elsődleges kezelésre refrakter beteg, kevesebben kaptak RT-t. A relapsuskor limitált stádiumú betegséggel rendelkezók és akik PET-pozitívak voltak az AHSCT előtt, jobb hároméves OS-t és PFS-t mutattak, ha kaptak RT-t, mint azok, akik nem, de a különbség nem volt szignifikáns $(91,7 \%$ vs. $62,3 \%, \mathrm{p}=0,14,67,5 \%$ vs. $50 \%, \mathrm{p}=0,22$ ).

Hasonlóan, más vizsgálatok sem tudták megerősíteni a peritranszplantációs RT szignifikánsan jobb hatását az OS-re és PFS-re [25-28], de ezekben a vizsgálatokban az RT-t kapó csoportban több bulky tumoros volt.

Összességében érintett mezős irradiáció lokális aktív betegség esetén javasolható, inkább a transzplantációt követően, korábban, esetleg nagyobb dózisban és akkor, ha az érintett régióra korábban sugárkezelést nem kapott a beteg. Növelheti a túlélést és késleltetheti a kemoterá- 
pia szükségességét, de csak kevés beteg gyógyul mindössze a sugárkezeléstól $[25,29,30]$, így további kezelések csak ritkán kerülhetőek el.

\section{Hagyományos kemoterápiák}

A hagyományos kemoterápiák közül a gemcitabin, etopozid, vinorelbin, vinblastin, liposomalis doxorubicin és bendamustin adása merül fel monokemoterápiaként, amelyek mellett az ORR 22-72\%, CR 12-51 [31]. A polikemoterápiák közül ugyanazoknak a kezeléseknek van szerepe, amelyeket a transzplantációt megelőzően is alkalmazhatunk (például: GDP, DHAP, ICE, IGEV, ASHAP, ChIVPP), ezek hatékonyabbak a monokemoterápiáknál, az ORR: 69-100\%, a CR: 17-88\% [31]. Azonban kérdéses, hogy tudunk-e még olyan kemoterápiát, polikemoterápiás kezelést alkalmazni, amelyet nem kapott, illetve amelyre várhatóan nem refrakter. Ezek hatására mind a myeloszuppresszió, mind a második malignus folyamatok kialakulásának a rizikója fokozott.

\section{Új kezelési módszerek}

\section{Brentuximab vedotin}

A brentuximab vedotin (BV) egy anti-CD30 antitest és a monometil auristatin E-konjugátuma, amely tubulinpolimerizációt gátol. AHSCT-t követően relabáló vagy legalább két megelőző polikemoterápia sikertelensége esetén klasszikus Hodgkin-lymphomában már elérhető, Magyarországon jelenleg tételes finanszírozás keretében. Relabált/refrakter betegeknél klinikai vizsgálatok 5672\%-os ORR-t, illetve 17-38\%-os CR-arányt igazoltak [32]. A fázis 3 AETHERA vizsgálat 329, nagy rizikójú (refrakter betegség, 12 hónapon belüli relapsus vagy 12 hónapon túli extranodalis érintettséggel járó relapsus miatt transzplantált), AHSCT után lévő betegnél alkalmazta a transzplantáció után egy évig a brentuximab vedotint [33]. Bár az OS-ben nem mutatkozott különbség - tekintettel arra, hogy a vizsgálat cross-over elrendezésú volt -, a kétéves PFS szignifikánsan jobb volt a placebocsoporténál ( $63 \%$ vs. $51 \%, p=0,001)$ [33]. Ezen vizsgálat alapján a nagy rizikójú betegek brentuximab vedotinnal történő konszolidációs kezelése javasolt az AHSCT után. A BV-kezelés jól tolerálható, ambulánsan alkalmazható, magas válaszarány érhető el, így AHSCT után, relapsus esetén, elsőként javasolt alkalmazása. Legjelentősebb mellékhatása a betegek 22-73\%-ban [32] észlelhető neutropenia és a szenzoros perifériás neuropathia, de ezek döntő többségben kezelhetőek.

\section{Bendamustin}

A bendamustin az alkilálószerekkel és a purinanalógokkal is szerkezeti hasonlóságot mutat, de sem in vitro, sem in vivo nem mutat keresztrezisztenciát $[34,35]$.
Relabáló és refrakter HL-ben több vizsgálat igazolta hatékonyságát, az ORR 53 és $78 \%$, a CR 33 és $29 \%$ volt.

\section{Brentuximab vedotin + bendamustin}

Eltérő hatásmechanizmusuk, kedvező mellékhatásprofiljuk alapján kombinációban történő alkalmazásuk is felmerült. A BV és bendamustin kombinálása jó eredményeket mutatott 41 HL és egy ALCL esetében (ORR 67\%, CR 19\%) [35]. Ötvenöt primer kemorefrakter HLben az ORR 93\%, a CR 73\% volt, ami nagyon jelentős eredmény [36]. Saját tapasztalataink alapján is jó hatékonyságú, a transzplantációig áthidaló kezelésként jól alkalmazható.

\section{Rituximab}

A rituximab a CD20 elleni monoklonális antitest, amely hatásos lehet HL-ben. Részben a mikrokörnyezeti CD20-pozitív sejtek, a HRS-sejtek részleges CD20-pozitivitása, a HL-es őssejtek eliminálása, valamint a CD20pozitív nodularis lymphocyta predomináns HL-ben is igazolt hatékonysága miatt. Huszonkét klasszikus HL-es betegben alkalmazva az ORR $22 \%$ volt [37].

A rituximabot más kemoterápiákkal együtt is próbálták alkalmazni (például gemcitabin [38]), de ezek egyértelmú hatékonysága nem igazolt. In vitro megfigyelések alapján a bendamustin és rituximab között szinergizmus lehet [39], így e két szer kombinációja javíthatja az eredményeket. Azonban az immunszuppresszív hatás miatt fokozott infekcióhajlam észlelhetó, erre alkalmazásakor fokozottan figyelni kell.

\section{Immunterápia}

\section{PDl-gátlók}

A programozott sejthalál (PD-1) fehérje a T-sejt mediálta immunválasz szabályozásában vesz részt. A PD-1-gátlók reaktiválhatják a tumorspecifikus T-sejteket, fokozhatják a T-sejtek tumorellenes aktivitását.

HL-ben hatásosságukat magyarázza, hogy a ReedSternberg-sejtekben a 9p24.1 kromoszóma eltérése egy visszatérő genetikai eltérés (NS altípusú HL-ben), amely a PD-1-ligandok overexpressziójához vezet, illetve ezt szintén fokozza az EBV-fertőzés is, így EBV-pozitív HL-es betegeknél is fokozott expressziót észlelhetünk [40].

A nivolumab egy humán monoklonális $\operatorname{IgG}_{4}$ antitest a PD-1 ellen. Huszonhárom HL-es betegnél alkalmazva, az ORR $87 \%$, a CR 17\%. A PFS 24 hétnél $86 \%$ volt a teljes beteganyagban. A mellékhatások döntôen grade 1-2 súlyosságúak, a betegek $56 \%$-ában észlelték (kiütés, thrombocytopenia, fáradtság, köhögés stb.), grade 3 események (MDS, emelkedett lipázszint, stomatitis, lymphopenia) ritkák, a betegek 22\%-ában észlelték [40]. 
A másik PDl-gátló a pembrolizumab, amellyel 31 beteget kezeltek [41], az ORR 65\% volt, a CR 16\%, a remissziók 70\%-a 24 hétnél tovább tartott.

Fázis 2 vizsgálatban a nivolumabot 80 , AHSCT után lévő, BV-kezelésben részesült betegnél alkalmazták. Az ORR 66,3\% volt. A leggyakoribb AE-k a fatigue (25\%), infúziós reakció $(20 \%)$ és kiütés (16\%), a grade 3-4 súlyosságúak közül a neutropenia (5\%) és az emelkedett lipázszint $(5 \%)$. Három beteg exitált a vizsgálat ideje alatt, egyikőjük sem a kezelés következtében [42]. Hasonlóan, a pembrolizumabot fázis 2 vizsgálat során alkalmazva, mind az AHSCT- és BV-kezelés után, mind az AHSCT-re nem alkalmas, BV-t kapó csoportban hatásosnak találták, az ORR 70\% és 80\% volt.

Az FDA 2016 májusában a nivolumab, 2017 márciusában pedig a pembrolizumab alkalmazását is elfogadta relabált/refrakter HL kezelésére AHSCT- és BV-kezelés után.

Jelenleg nem ismert, hogy a PDl-gátlókra adott válasz mennyire tartós, mennyi ideig kell alkalmazni. A komplett remissziók kis arányának okaként felmerül a PET/ CT jelenlegi értékelésének problémája is, hiszen gyakran megfigyelhető flare jelenség és pseudoprogresszió a kezelés elején [43], de nem kizárható, hogy önmagában nem lesz elég a tartós remisszió a gyógyulás eléréséhez. Számos új, autoimmun mellékhatással is számolnunk kell alkalmazásuk során. Fontos, hogy a jelenleg AHSCT után relabáló csoportnál kuratív kezelésként (még ha kis számban is) csak az allogén SCT jöhet szóba, amelyet a PDl-gátlók alkalmazását követően a GVHD, VOD és lázas betegségek kialakulásának fokozott rizikója miatt körültekintően kell alkalmazni.

\section{Allogén transzplantációra alkalmas beteg kezelése}

\section{Elsö eset}

Hypertoniás férfi betegünknél 2006 októberében, 35 éves korában igazolódott nodular sclerosis altípusú, III. stádiumú Hodgkin-lymphoma, ami miatt hat ciklus ABVD-kezelésben részesült. Öt évvel később szövettanilag is igazolt relapsus miatt DHAP-, majd IGEV-kezelést kapott. KMR elérését követően, 2012. március 19-én megtörtént az AHSCT, és 2013. márciusig fenntartó kezelésként brentuximab vedotin kezelésben részesült a beteg. A kezelés végén elvégzett PET/CT ismételt relapsust igazolt. Hat ciklus rituximab-bendamustin kezelés mellett KMR-be került, ezt követôen 11 hónapig betegsége remisszióban volt. Az allogén transzplantáció lehetősége már ekkor felmerült. Testvér donora nem volt, a donorkeresés hosszú ideig sikertelen volt, így haploidentikus transzplantációra készültünk. 2014. szeptemberben ismételt relapsus miatt a korábban hatásosnak bizonyuló rituximab-bendamustin kezelést ismételtük hat ciklusban, eredményesen. Az elvégzett restaging
PET/CT mediastinalis progressziót igazolt, így annak érintett mezős irradiációja, 36 Gy összdózisban megtörtént. Ezután a beteg ismét KMR-be került, és 2015. augusztus 25-én megtörtént a haploidentikus (anyai donor) transzplantáció. A poszttranszplantációs időszakban haemorrhagiás cystitis, pneumonia, majd kamrába törő állományvérzés alakult ki, s végül a beteg 2016. január 29-én, a 131. napon exitált, a Hodgkin-lymphoma remisszióban volt.

\section{Allogén transzplantációra (még) nem alkalmas beteg}

\section{Második eset (2. ábra)}

Nőbetegünk anamnézisében hypertonia és spondylosis szerepelt. 2011-ben, 51 éves korában igazolódott kevert sejtes altípusú, III/A stádiumú Hodgkin-lymphomája (IPS: 1, EBV-negatív). Hat ciklus ABVD-t követően elvégzett $\mathrm{PET} / \mathrm{CT}$ vizsgálat a mediastinalis nyirokcsomóknál progressziót igazolt, így érintett mezős irradiáció történt 36 Gy összdózisban. 2012. decemberben, a kezelés befejezését követôen disszeminált relapsus jelentkezett, a javasolt kezelést (DHAP és AHSCT) 10 hónappal később fogadta csak el. DHAP-, majd IGEVkezelés alkalmazását követően jó parciális remisszióban 2014. márciusban megtörtént az AHSCT, amit 2014 áprilisában a bal oldali nyaki patológiás nyirokcsomók érintett mezős irradiációja követett. Egy év elteltével ismételt relapsus miatt brentuximab vedotin-bendamustin kezelést alkalmaztunk. KMR alakult ki, de tekintettel az ismétlődő infekciókra, négy ciklust követően csak a brentuximab vedotin monoterápia folytatása mellett döntöttünk. 2016. augusztusban progresszió volt észlelhető, így nivolumabkezelés indult, amelyből eddig négy ciklust kapott meg, ellenőrző PET/CT vizsgálat 2017. februárban komplett remissziót igazolt.

Testvére nincs, életkora miatt leginkább haploidentikus transzplantáció merül fel, amelyet egyelőre elutasít.

\section{Harmadik eset (3. ábra)}

Fiatal nőbetegünk anamnézisében mitralis prolapsus szerepel. 2014. februárban, 24 éves korában igazolódott IV/B stádiumú Hodgkin-lymphoma, nem differenciált altípus. ABVD-kezelés indult, amelynek negyedik ciklusát követően elvégzett interim PET/CT vizsgálat pozitív volt, így IGEV-kezelés indult, amely első ciklusát követően további progresszió volt észlelhető. Brentuximab vedotin-DHAP indult stabil betegség mellett. 2014. október 29-én megtörtént az AHSCT R-BEAM-Br kondicionálás után. A 100. napi kontroll PET/CT a mediastinum érintettségét igazolta, így 30 Gy összdózisú sugárkezelésben részesült. 2015. júliusban ismét mediastinalis relapsus alakult ki, tekintettel a korábbi kemo-, immunkemo- és radioterápiák sikertelenségére 


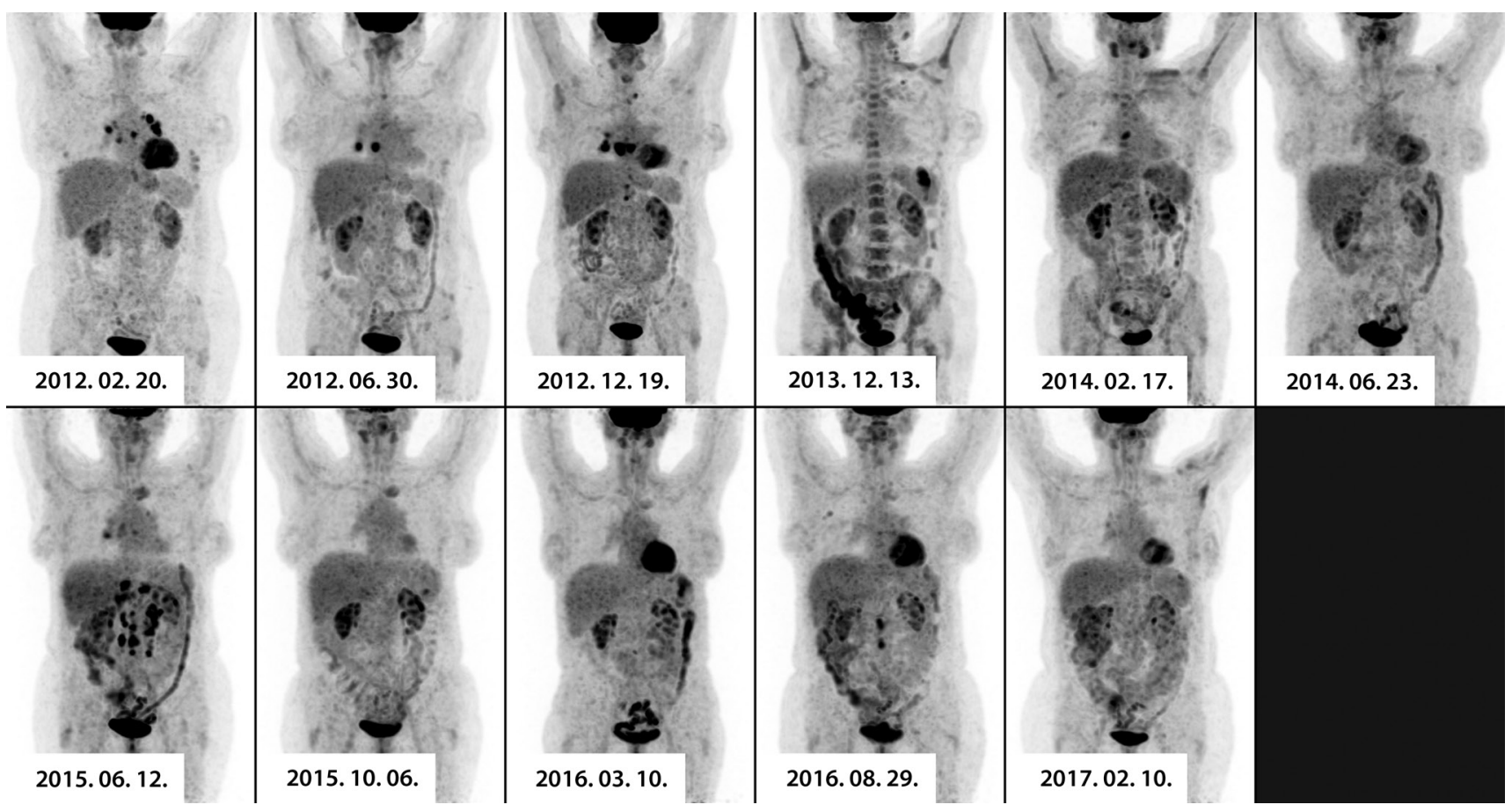

2. ábra $\mid$ Kevert sejtes altípusú, kezdetben III/A stádiumú Hodgkin-lymphoma (IPS: 1, EBV-negatív). Hat ciklus ABVD-t követően 2012. február 20-án mediastinalis progresszió miatt érintett mezős irradiáció. 2012. december 19-én igazolódott disszeminált relapsus. DHAP-, IGEV-kezeléseket követően 2014. márciusban megtörtént az AHSCT, amelyet a bal oldali nyaki nyirokcsomók érintett mezős irradiációja követett. 2014. június 23-án komplett metabolikus remisszió volt igazolható. 2015. június 12-én ismét relapsus, négy ciklus brentuximab vedotin-bendamustin kezelés után 2016. március 10-én a PET/CT KMR-t igazolt, a brentuximab vedotin monoterápiát folytattuk. 2016. augusztus 29-én PET/CT-n progresszió, nivolumabkezelés indult, amelyből eddig négy ciklust kapott meg, ellenőrző PET/CT vizsgálat 2017. február 10-én komplett remissziót igazolt
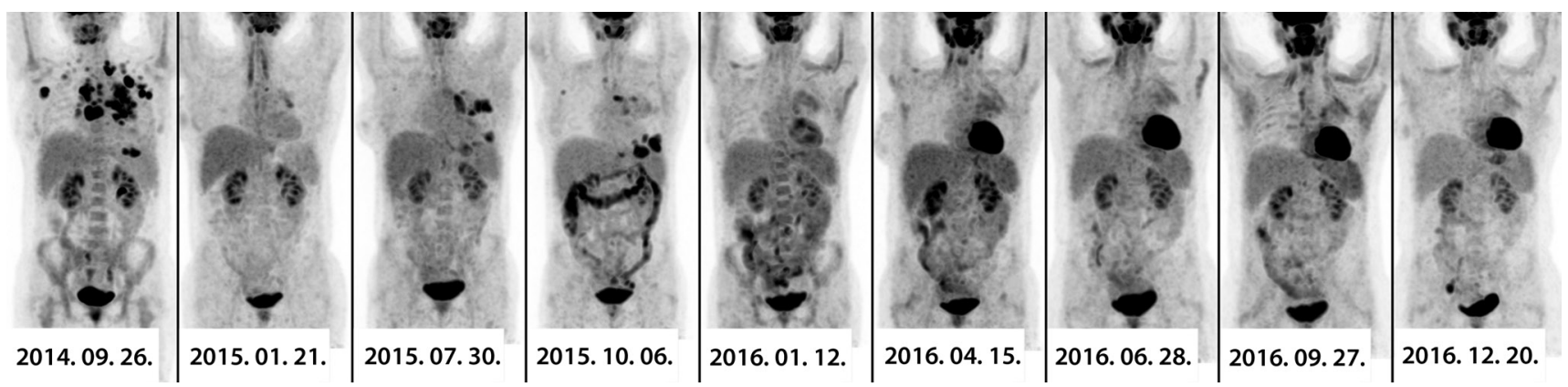

3. ábra

\begin{abstract}
Nem differenciált altípusú, kezdetben IV/B stádiumú Hodgkin-lymphoma. Négy ciklus ABVD-kezelést követôen progresszió, IGEV-kezelésre váltottak, további progresszió miatt brentuximab vedotin-DHAP indult, az ezt követő PET/CT (2014. szeptember 26.) stabil betegséget jelzett. 2014. október 29-én AHSCT, kontroll PET/CT (2015. január 21.) Deauville 4 score-t igazolt a mediastinum érintettségével, így mediastinalis irradiáció történt. 2015. júliusban mediastinalis relapsus, tekintettel a korábbi kemo-, immunkemo- és radioterápiák sikertelenségére PDl-gátló (pembrolizumab) kezelés indult októberben, 18 ciklust követően jelenleg parciális remisszió észlelhető
\end{abstract}

PDl-gátló kezelést javasoltunk. Pembrolizumabkezelés indult, 18 ciklust követően jelenleg parciális remisszió észlelhető, klinikailag jól van.

\section{Következtetés}

Az AHSCT után relabáló Hodgkin-lymphomás betegek túlélésének javítása az egyik legfontosabb feladat a HLes betegek kezelése során. Az AHSCT időpontjában számos tényező jelzi előre a fokozott rizikót relapsusra, amelyek közül a legfontosabb a remisszió mértéke az AHSCT időpontjában, így a pretranszplantációs PET/
CT-nek kiemelt jelentősége van, ennek elvégzése minden betegnél kötelező AHSCT előtt. Amennyiben a betegség nincs komplett remisszióban, a transzplantáció várható eredménye kedvezőtlenebb, ennek megelőzése az elsődleges cél, további salvage-kezelések (brentuximab vedotin + kemoterápia [főleg bendamustin], PDlgátlók [bár ebben az indikációban törzskönyvezve még nincs]) használatával. Amennyiben a beteg a relapsusra fokozott rizikóval rendelkezik az AHSCT után (refrakter betegség, 12 hónapon belüli relapsus vagy 12 hónapon túli extranodalis érintettséggel járó relapsus miatt transzplantált), fenntartó BV-kezelés jelenleg a reálisan 
elérhető kezelési módszer, hogy a relapsusmentes túlélést növeljük, de bizonyos esetekben a korai, lokális sugárkezelésnek is helye van. AHSCT utáni relapsus esetében a hagyományos kemo-, sugárterápián túl, a brentuximab vedotin és a nivolumab érhető el, amennyiben a beteg alkalmas rá, és betegsége is megfelelő remisszióba kerül, az allogén SCT kuratív hatású lehet, a haploidentikus allo-SCT reménykeltő mind a könnyebben elérhető donorok, mind eredményei miatt. A betegek kezelését azonban nehezíti, hogy ekkorra már súlyosan előkezeltek, és az ebből származó mellékhatásokból eredő társbetegségek korlátozhatják az alkalmazható terápiás módokat. Mindezek alapján fontos az új, az eddigiektől eltérő támadáspontú és mellékhatás-profilú kezelések - akár kombinált - alkalmazása, amelyre prospektív, nagy betegszámú klinikai vizsgálatok szükségesek. Addig is fontos a lehető leginkább személyre szabott terápiák alkalmazása, amellyel a túlélés növelhető.

Anyagi támogatás: A közlemény megírása anyagi támogatásban nem részesült.

Szerzői munkamegosztás: I. Á., M. Zs.: A kézirat megírása és ellenőrzése. J. Á., M. F.: Segítség az anyaggyưjtésben és -feldolgozásban. S. Zs., U. M.: A transzplantációs adatok összegzése. A cikk végleges változatát valamennyi szerző elolvasta és jóváhagyta.

Érdekeltségek: A szerzőknek nincsenek érdekeltségeik.

\section{Irodalom}

[1] Majhail NS, Weisdorf DJ, Defor TE, et al. Long-term results of autologous stem cell transplantation for primary refractory or relapsed Hodgkin's lymphoma. Biol Blood Marrow Transplant. 2006; 12: 1065-1072.

[2] Crump M. Management of Hodgkin lymphoma in relapse after autologous stem cell transplant. Hematology Am Soc Hematol Educ Program 2008; 1: 326-333.

[3] Kewalramani T, Nimer SD, Zelenetz AD, et al. Progressive disease following autologous transplantation in patients with chemosensitive relapsed or primary refractory Hodgkin's disease or aggressive non-Hodgkin's lymphoma. Bone Marrow Transplant. 2003; 32: 673-679.

[4] Bierman PJ, Lynch JC, Bociek RG, et al. The International Prognostic Factors Project score for advanced Hodgkin's disease is useful for predicting outcome of autologous hematopoietic stem cell transplantation. Ann Oncol. 2002; 13: 1370-1377.

[5] Spaepen K, Stroobants S, Dupont P, et al. Prognostic value of pretransplantation positron emission tomography using fluorine 18 -fluorodeoxyglucose in patients with aggressive lymphoma treated with high-dose chemotherapy and stem cell transplantation. Blood 2003; 102: 53-59.

[6] Hahn T, McCarthy PL, Carreras J, et al. Simplified validated prognostic model for progression-free survival after autologous transplantation for Hodgkin lymphoma. Biol Blood Marrow Transplant. 2013; 19: 1740-1744.

[7] Sureda A, Constans M, Iriondo A, et al., for the Grupo Español de Linfomas/Trasplante Autólogo de Médula Osea Cooperative Group. Prognostic factors affecting long-term outcome after stem cell transplantation in Hodgkin's lymphoma autografted after a first relapse. Ann Oncol. 2005; 16: 625-633.

[8] Moskowitz AJ, Yahalom J, Kewalramani T, et al. Pretransplantation functional imaging predicts outcome following autologous stem cell transplantation for relapsed and refractory Hodgkin lymphoma. Blood 2010; 116: 4934-4937.

[9] Gentzler RD, Evens AM, Rademaker AW, et al. F-18 FDG-PET predicts outcomes for patients receiving total lymphoid irradiation and autologous blood stem-cell transplantation for relapsed and refractory Hodgkin lymphoma. Br J Haematol. 2014; 165: 793-800.

[10] Moskowitz CH, Yahalom J, Zelenetz AD, et al. High-dose chemo-radiotherapy for relapsed or refractory Hodgkin lympho$\mathrm{ma}$ and the significance of pre-transplant functional imaging. $\mathrm{Br}$ J Haematol. 2010; 148: 890-897.

[11] Moskowitz AJ, Perales MA, Kewalramani T, et al. Outcomes for patients who fail high dose chemoradiotherapy and autologous stem cell rescue for relapsed and primary refractory Hodgkin lymphoma. Br J Haematol. 2009; 146: 158-163.

[12] Arai S, Fanale M, DeVos S, et al. Defining a Hodgkin lymphoma population for novel therapeutics after relapse from autologous hematopoietic cell transplant. Leuk Lymphoma 2013; 54: 2531-2533.

[13] Rashidi A, Ebadi M, Cashen AF. Allogeneic hematopoietic stem cell transplantation in Hodgkin lymphoma: a systematic review and meta-analysis. Bone Marrow Transplant. 2016; 51: 521528.

[14] Robinson SP, Sureda A, Canals C, et al. Reduced intensity conditioning allogeneic stem cell transplantation for Hodgkin's lymphoma: identification of prognostic factors predicting outcome. Haematologica 2009; 94: 230-238.

[15] Sureda A, Robinson S, Canals C, et al. Reduced-intensity conditioning compared with conventional allogeneic stem-cell transplantation in relapsed or refractory Hodgkin's lymphoma: an analysis from the Lymphoma Working Party of the European Group for Blood and Marrow Transplantation. J Clin Oncol. 2008; 26: 455-462.

[16] Luznik L, O'Donnell PV, Symons HJ, et al. HLA-haploidentical bone marrow transplantation for hematologic malignancies using nonmyeloablative conditioning and high-dose, posttransplantation cyclophosphamide. Biol Blood Marrow Transplant. 2008; 14: 641-650.

[17] Burroughs LM, O'Donnell PV, Sandmaier BM, et al. Comparison of outcomes of HLA-matched related, unrelated, or HLAhaploidentical related hematopoietic cell transplantation following nonmyeloablative conditioning for relapsed or refractory Hodgkin lymphoma. Biol Blood Marrow Transplant. 2008; 14: 1279-1287.

[18] Raiola A, Dominietto A, Varaldo R, et al. Unmanipulated haploidentical BMT following non-myeloablative conditioning and post-transplantation CY for advanced Hodgkin's lymphoma. Bone Marrow Transplant. 2014; 49: 190-194.

[19] Gayoso J, Balsalobre P, Castilla-Llorente C, et al. Haploidentical stem cell transplantation (HAPLO-HSCT) with reduced intensity conditioning (RIC) regimens and high dose cyclophosphamide post-transplant (HD-CY) as GVHD prophylaxis in patients with relapsed or refractory Hodgkin's disease: multicentric Spanish experience. Blood 2013; 122: 3406.

[20] Phillips GL, Wolff SN, Herzig RH, et al. Treatment of progressive Hodgkin's disease with intensive chemoradiotherapy and autologous bone marrow transplantation. Blood 1989; 73: 2086-2092.

[21] Wadhwa P, Shina DC, Schenkein D, et al. Should involved-field radiation therapy be used as an adjunct to lymphoma autotransplantation? Bone Marrow Transplant. 2002; 29: 183-189.

[22] Mundt AJ, Sibley G, Williams S, et al. Patterns of failure following high-dose chemotherapy and autologous bone marrow transplantation with involved field radiotherapy for relapsed/re- 
fractory Hodgkin's disease. Int J Radiat Oncol Biol Phys. 1995; 33: 261-270.

[23] Milgrom SA, Jauhari S, Plastaras JP, et al. A multi-institutional analysis of peritransplantation radiotherapy in patients with relapsed/refractory Hodgkin lymphoma undergoing autologous stem cell transplantation. Cancer 2017; 123: 1363-1371.

[24] Goda JS, Massey C, Kuruvilla J, et al. Role of salvage radiation therapy for patients with relapsed or refractory Hodgkin lymphoma who failed autologous stem cell transplant. Int J Radiat Oncol Biol Phys. 2012; 84: e329-e335.

[25] Levis M, Piva C, Filippi AR, et al. Potential benefit of involvedfield radiotherapy for patients with relapsed-refractory Hodgkin's lymphoma with incomplete response before autologous stem cell transplantation. Clin Lymphoma Myeloma Leuk. 2017; 17: 14-22.

[26] Poen JC, Hoppe RT, Horning SJ. High-dose therapy and autologous bone marrow transplantation for relapsed/refractory Hodgkin's disease: the impact of involved field radiotherapy on patterns of failure and survival. Int J Radiat Oncol Biol Phys. 1996; 36: 3-12.

[27] Wendland MM, Asch JD, Pulsipher MA, et al. The impact of involved field radiation therapy for patients receiving high-dose chemotherapy followed by hematopoetic progenitor cell transplant for the treatment of relapsed or refractory Hodgkin's disease. Am J Clin Oncol. 2006; 29: 189-195.

[28] Kahn S, Flowers C, Xu Z, et al. Does the addition of involved field radiotherapy to high-dose chemotherapy and stem cell transplantation improve outcomes for patients with relapsed/ refractory Hodgkin lymphoma? Int J Radiat Oncol Biol Phys. 2011; 81: 175-180.

[29] Campbell B, Wirth A, Milner A, et al. Long-term follow-up of salvage radiotherapy in Hodgkin's lymphoma after chemotherapy failure. Int J Radiat Oncol Biol Phys. 2005; 63: 1538-1545.

[30] Josting A, Nogová L, Franklin J, et al. Salvage radiotherapy in patients with relapsed and refractory Hodgkin's lymphoma: a retrospective analysis from the German Hodgkin Lymphoma Study Group. J Clin Oncol. 2005; 23: 1522-1529.

[31] Alinari L, Blum KA. How I treat relapsed classical Hodgkin lymphoma after autologous stem cell transplant. Blood 2016; 127: 287-295

[32] Illés Á, Jóna Á, Miltényi Zs: Brentuximab vedotin for treating Hodgkin's lymphoma: an analysis of pharmacology and clinical efficacy. Expert Opin Drug Metab Toxicol. 2015; 11: 451-459.

[33] Moskowitz CH, Nademanee A, Masszi T, et al. Brentuximab vedotin as consolidation therapy after autologous stem-cell trans- plantation in patients with Hodgkin's lymphoma at risk of re lapse or progression (AETHERA): a randomised, double-blind, placebo-controlled, phase 3 trial. Lancet 2015; 385: 1853-1862.

[34] Cheson BD, Rummel MJ. Bendamustine: Rebirth of an old drug. J Clin Oncol. 2009; 27: 1492-1501.

[35] Sawas A, Connors JM, Kuruvilla JG, et al. The combination of brentuximab vedotin $(\mathrm{Bv})$ and bendamustine $(\mathrm{B})$ demonstrates marked activity in heavily treated patients with relapsed or refractory Hodgkin lymphoma (HL) and anaplastic large T-cell lymphoma (ALCL): results of an International Multi Center Phase I/II Experience. Blood 2015; 126: 586.

[36] LaCasce AS, Bociek G, Sawas A, et al. Brentuximab vedotin plus bendamustine: a highly active salvage treatment regimen for patients with relapsed or refractory Hodgkin lymphoma. Blood 2015; 126: 3982.

[37] Younes A, Romaguera J, Hagemeister F, et al. A pilot study of rituximab in patients with recurrent, classic Hodgkin disease. Cancer 2003; 98: 310-314.

[38] Oki Y, Pro B, Fayad LE, et al. Phase 2 study of gemcitabine in combination with rituximab in patients with recurrent or refractory Hodgkin lymphoma. Cancer 2008; 112: 831-836.

[39] Tageja N, Nagi J. Bendamustine: something old, something new. Cancer Chemother Pharmacol. 2010; 66: 413-423.

[40] Ansell SM, Lesokhin AM, Borrello I, et al. PD-1 blockade with nivolumab in relapsed or refractory Hodgkin's lymphoma. N Engl J Med. 2015; 372: 311-319.

[41] Armand P, Shipp MA, Ribrag V, et al. Programmed death-1 blockade with pembrolizumab in patients with classical Hodgkin lymphoma after brentuximab vedotin failure. J Clin Oncol. 2016 Jun 27. pii: JCO673467. [Epub ahead of print]

[42] Younes A, Santoro A, Shipp M, et al. Nivolumab for classical Hodgkin's lymphoma after failure of both autologous stem-cell transplantation and brentuximab vedotin: a multicentre, multicohort, single-arm phase 2 trial. Lancet Oncol. 2016; 17: 12831294.

[43] Cheson BD, Ansell S, Schwartz L, et al. Refinement of the Lugano Classification lymphoma response criteria in the era of immunomodulatory therapy. Blood 2016; 128: 2489-2496.

(Miltényi Zsófia dr., Debrecen, Nagyerdei krt. 98., 4032 e-mail: mil03@freemail.hu)

\title{
A rendezvények és kongresszusok híranyagának leadása
}

\author{
a lap megjelenése előtt legalább 40 nappal lehetséges, a 6 hetes nyomdai átfutás miatt. \\ Kérjük megrendelőink szíves megértését.
}

A híranyagokat a következő címre kérjük:

Orvosi Hetilap titkársága: edit.budai@akademiai.hu

Akadémiai Kiadó Zrt. 